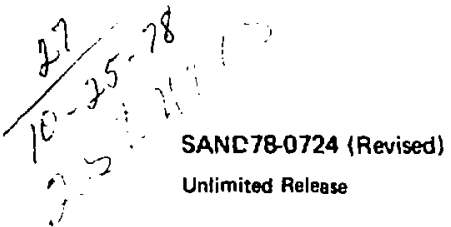

\title{
MASTER
}

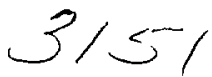

\section{Plutonium Accident Resistant Container Project}

John A. Anderseri

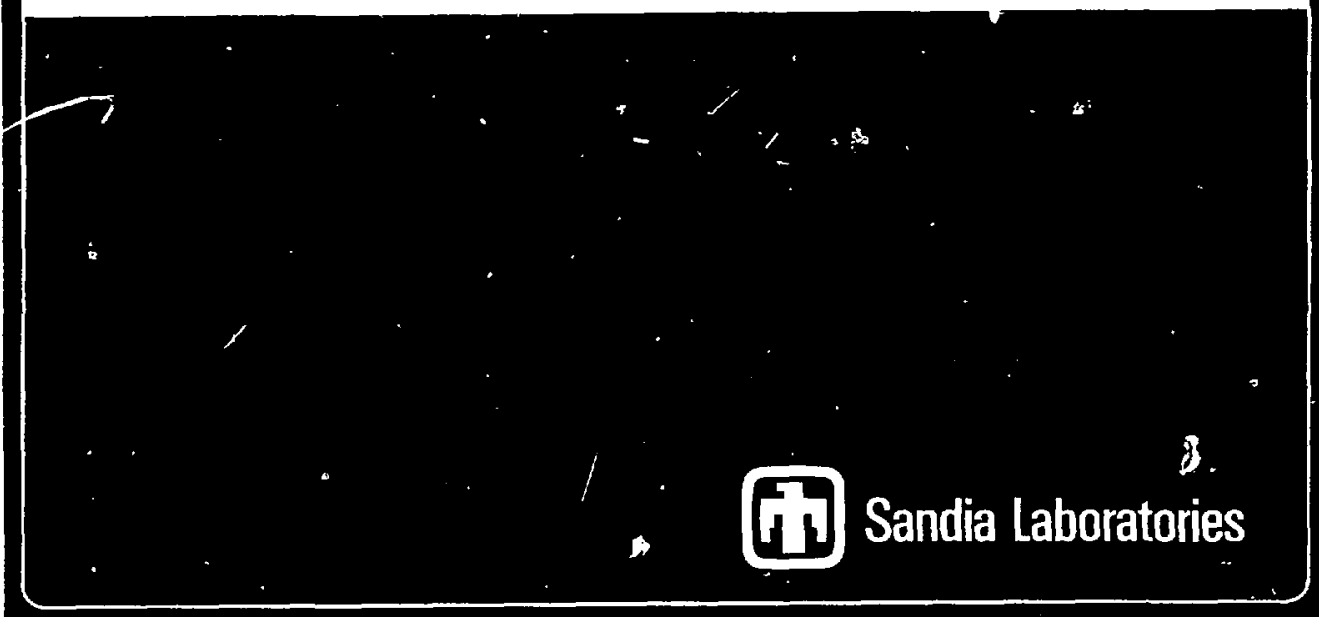

SF 2900 0(7.73) 
SAND78-0724 (Reviged)

Unlimited Release

Printed May 1978

Revised September 1978

PLUTONIUM ACCIDENT RESISTANT CONTAINER PROJECT*

John A. Andersen

Transportation Safety Technology Division 5433

Sandia Laboratories, Albuquerque, New Mexico 87185

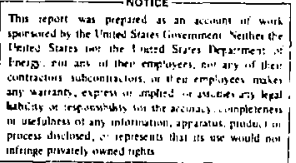

ABSTRACT

The PARC (plutonlum accident registant container) project resulted in the design, development, and certification testing of a rrashworthy adr-transportable plutonium package (shipping container) for certification by the USNRC (Nuclear Regulatory Commission). This PAT-1 (plutonium air transportable) package survives a very severe sequenthal test program of iropact, crush, puncture, slash, burn, and water immergion. There is also an individual hydrostatic pressure test. The package has a payload mase capacity of $2 \mathrm{~kg}$ of $\mathrm{PuO}_{2}$ and a the rmal capacity of 25 watts. The design rationale for very high energy absorption (Impact, crush, puncture, and slash protection) with residual highlevel fire protection, resulted in a reasonably small air-transportable package, advancing the packaging state-of-art. Optimization design iterationg were utilized in the areas of impact energy absorption and stress and thermal analysis. Package test resulis are presented in relation to radioactive materials containment acceptance critsria, shielding and criticality standaras.

\footnotetext{
${ }^{*}$ Project funded by the United States Nuclear Regulatory Commission.
} 


\section{ACKNOWLEDGMENTS}

The author is indebted to a number of people who, directly or indirectly, have been Inetrumental in thls work. Among many expert and dedicated people, the contributions of Brlan J. Joseph were outgtanding. Also, William Laha, Jerry Wallace, Ken Cole, Walt Von Riegemann, Ron Pope, Bob Jefferson, Blll Snyder, Mike Stone, Blll Hartman, Will Schmidt, Jim Stark, Steve Sutherland, Lloyd Nelson, Nick DeLollis, Charlie Mark, Tom Duffey, Steve Dupree, Bob Nilgan, Van Luhrs, Hank Guttmann, Phil Owena, and Rick Matchette made aigniflcant independent contributions. 


\section{CONTENTS}

Introduction and General

Air Qualified Overpack (AQ-1)

Containment Vessel (TB-1)

Product $\mathrm{Can}(\mathrm{PC}-1)$

Thermal Analysis

Test Program

Other

APPENDIX A -n Crush-Energy Absorption and Char Properties of Materials

\section{TABLES}

\section{Table}

I Qualification Criteria 8

II Acceptance Criteria. $\quad 9$

III Summary of Qualificationi Tests, PAT-1 Package 20

IV Examples of Allowable Mass Release Rates -- LAEA "A2, " Safety
Series No, 6 and NUREG-0360

$\mathrm{V} \quad$ Shielding and Criticality 21

V1 Results of $10 \mathrm{CFR} 71$ Qualification Tests, PAT-1 Package 22

VII Cantainment Vessel Integrity 23 
ILLUSTAATIONS

\begin{tabular}{|c|c|c|}
\hline Figure & & Page \\
\hline 1 & PAT-1 Package Exterior & 9 \\
\hline 2 & PAT-1 Plutonium Air Transportable Package, Cutaway & 10 \\
\hline 3 & AQ-1 Closure & 11 \\
\hline 4 & Accident Resistant Container Materiala Evaluation & 11 \\
\hline 5 & Char Performance & 12 \\
\hline 6 & Average Crush Stress for Redwood as a Function of Temperature & 13 \\
\hline 7 & Impact Energy Balance & 13 \\
\hline 8 & Impact Energy Balance & 14 \\
\hline 9 & PAT-1 Package Interior & 15 \\
\hline 10 & TB-1 Containment Vessel with PC-1 Product Can & 16 \\
\hline 12 & Containment Vessel Seal & 16 \\
\hline 12 & Containment Vessel Finite Element Streas Anelyois & 17 \\
\hline 13 & Finite Difference Internal Heat Model & 18 \\
\hline 14 & Finite Difference External Heat Model & 19 \\
\hline$A-1$ & Energy Absorbed per Unit Mass of Material & 25 \\
\hline $4-2$ & Energy Abaorbed per Lnit Volume of Material & 26 \\
\hline A-3 & $\begin{array}{l}\text { Comparison of Char Depths (Distance of Exposure Surface to } \\
550^{\circ} \mathrm{F} \text { Point) versus Time for an } 1850^{\circ} \mathrm{F} \text { Blackbody Radiation } \\
\text { Source }\end{array}$ & 27 \\
\hline$A-4$ & Typical Load-Deflection Curves for Redwood & 28 \\
\hline$A-\overline{5}$ & Average Crushing Stress vs. Temperature for Redwood & 28 \\
\hline$A-6$ & Specific Energv vs. Temperature for Redwood & 29 \\
\hline B- 1 & Regions trsed in Energy Balance Calculations & 31 \\
\hline
\end{tabular}




\section{PLUTONIUA ACCIDENT RESISTANT CONTAINER PRDILCT}

Introduction and General

A recent United States Publlc Law (94-79; August 9, 1975) restricts the air shipment of plutonium. This law reads, in part, that no plutonium (except for very small quantities of riaterial in medical devices) may be air transported until the NRC (U.S. Nuclear Regulatory Commission) ". . has certified that a safe container has been developed and tested which will not rupture under crash and blast testing equivalent to the crash and explosion of a high-flying aircraft. . . ." Although there were problems of transiating the general language of the law to technically meaningful definitions, very severe ausident-modeling criteria were developed by the viRC, which also engaged Sandia Laboratories in the development of a transportation package that would acceptably survive the new criteria. The initial tasks were to promulgate criteria and then to design a package to satisfy those criteria. Both the new criteria and the new package have been presented for approval to the Advisory Committee for Reactor Safeguards and the National Academy of Engineering's Ad-hoc Committee on the Air Transport of Plutonium. Results are being, or have been, presented to the U, S. Congress, as originally mandated.

The NRC criteria became a document defining those measures necessary to tualify and cerłify a package for the air transport of plutonium; hereafter, this will be referred to as the Qualification Criteria. The Qualification Criteria essentially consists of a test program with supporting rationale and stringent acceptance standards. The rationale embodies a maxinum credible accident approach, with very s, rere single-event accident elements applied seqientially to the same package. Also, certain individual tests are included as well as a requirement to conform to cxisting regulations.

That portion of the program performec at Sandia bears the acronym "PARC" for Plutonium Accident Resistant Container. The PARC project resulted in the development of the PAT-1 (Plutonium Air Transportable) Package. The package was designed concurrently with and in response to the Qualification Criteria and survives the sequential and individual tests of both the new and old criteria and meets the applicable acceptance standards in each case.

The Qualification Criteria are summarized in the next two tables; Table $J$ defines the test program of new sequential and individual tests, and also summarizes the tests of the existing regulations, 10 CFR 71. 
TABLE II

Acceptance Criterda

\section{Containment of Plutonium}

-- Release must be < IAEA A2 weekly quantity following test gequence of new criteria

-. "No release" from double contatnment following 10 CFR 71 normal or accident condtions measured as a leak rate - - ANSI N $14.5: 10^{-7} \mathrm{~cm}^{3} / \mathrm{s}$-- or as actual lose of surrogate: less than $20^{-8} \mathrm{~g}$, by fluorimetry

\section{Shielding}

- Normal transport - 49 CFR 173 requires that external radiation be limited to: $10 \mathrm{mrem} / \mathrm{hr}$ at $1 \mathrm{~m}$ (s $\mathrm{ft}$ ), and $200 \mathrm{mrem} / \mathrm{hr}$ at surface

- Pogtaccident - 10 CFR 71 requires that external radiation, following the more severe tests of the nevs criteria, be limited to:

$1000 \mathrm{mrem} / \mathrm{hr}$ at $1 \mathrm{~m}(3 \mathrm{ft})$

\section{Criticulity}

-- Undamaged single packages and large arrays must be subcritical per 10 CFR 71

-- Arrays oi damaged packages i. ust be suberitical per 10 CFR 71, following the more gevere tests of the new criteria

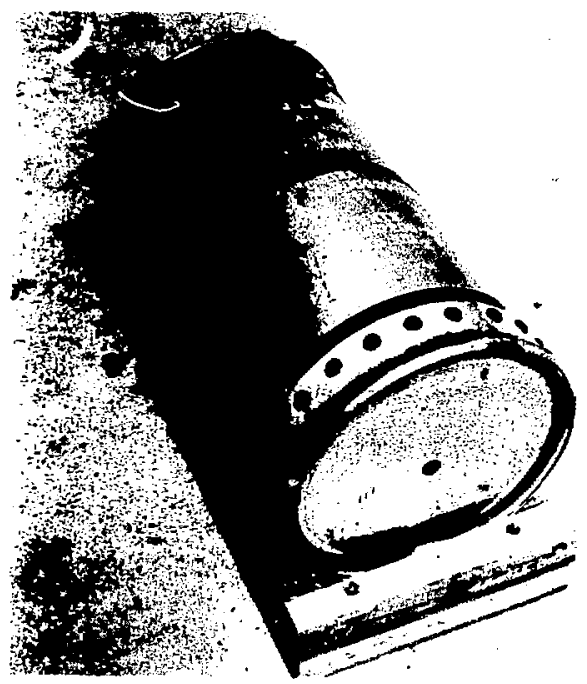

Figure 1. PAT-1 Package Exterior 


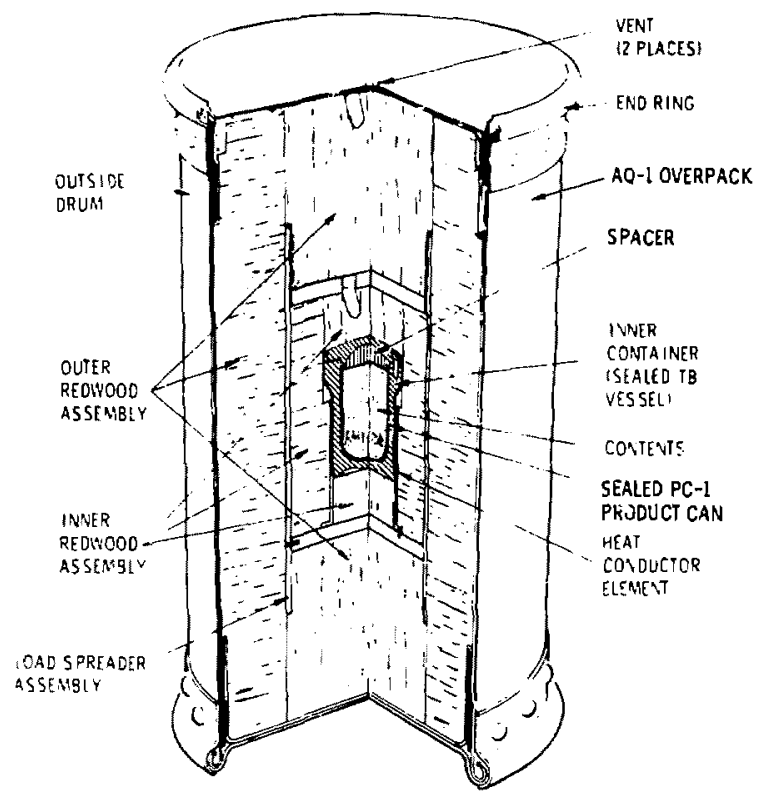

rigure 2. PAT-1 Plutonium Air Transportable l’ackage, Cutaway

\section{Air Qualitied Overpack (AQ-1)}

The AQ- 1 configuration consists of an outside drum, with at least two layera and in some $\therefore{ }^{\circ}$. ive layers of 16 gauge, $\mathbf{3 0 4}$ stainless steel; an outer and inner grain-oriented redwood $\therefore: \therefore$ with an interstitial load spreader assembly: and a heat conductor element.

The sutsite drum-ends, both top and bottom, are secured in a unicue manner, shown in Figure $;$, to permit reintively simple access to the container and yet retatn the removable parts in a violent crash.

One factor leading to the se ction of redwond as the shuck mitigator/thermal barrier is its high specifis energy absorption capability parallel with the grain, as indicated in Figure 4; redwood outranks most shock mitigators such as elastomeric and rigid foams, aluminum and stainless steel honeycombs, foam-filled honeycombs, and other natura, products. This capability was examined relative to density so as to constrain the final package size and weight while maintaining utility as an industrial air transportable package with a practical (although small) internal payloct. 


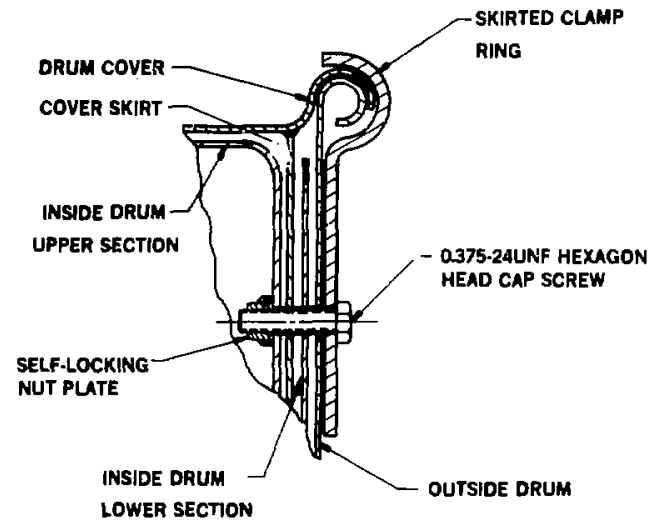

Figure 3. $A Q-1$ Closure

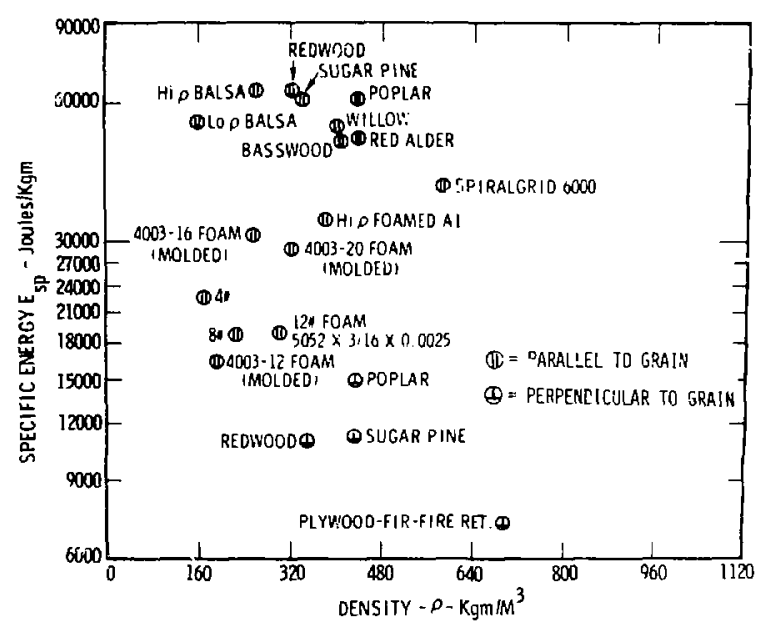

Figure 4. Accident Resistant Container Materials Evaluation 
Thermal bartict or chat performarce was the other principal characteristic leading to the choll. of rajwood, is indicated in Figure 5, redwoud rhar performanre rompares favorably with

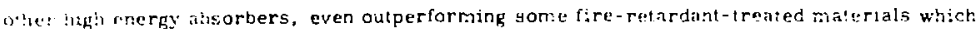
wer" id as efficient. Although balsa and some rigid foams slightly outperformed redwond in this regird, the former was too bulky for air transportable design and the latter wern rot as efficient in energy absorption.

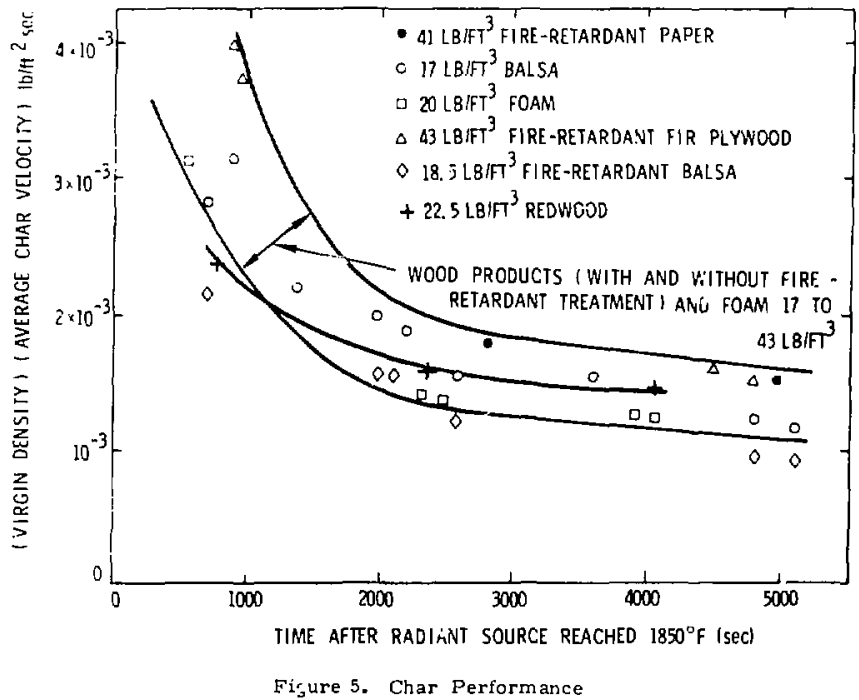

Sew redwood strength data, Figure 6, were generated to support design analysis across an appropriate broad temperature range. An impact energy balance analysis, Figure 7 , was iterated to op:imize the design application of the inner and outer regions of redwood and the interstitial aluminum load spreaders. Appendix A gives more complete information on the redwood data generated for this program; Appendix B summarizes the ene $B$ b balance impact analysis method.

Aluminum was chosen for the load-spreader assembly because of its favorable mass, st1: ngth, moduius, thermal conductivity, cost and availability. Load spreaders were found to be essential to distribute dynamic inertial compressive loading from the relatively small area loading of the containment vessel within the package, to a larger area of the shock-absorbing material. In a side or lateral impact, the tube is the principal load spreader; in an end or longitudinal impact, the dises are the principal load spreaders. Referring to Figure 2, the extended region of the tube, beyond the discs, deforms inward in a severe corner impact, constricting possible passage of the discs and containment vessel in an outward direction. 


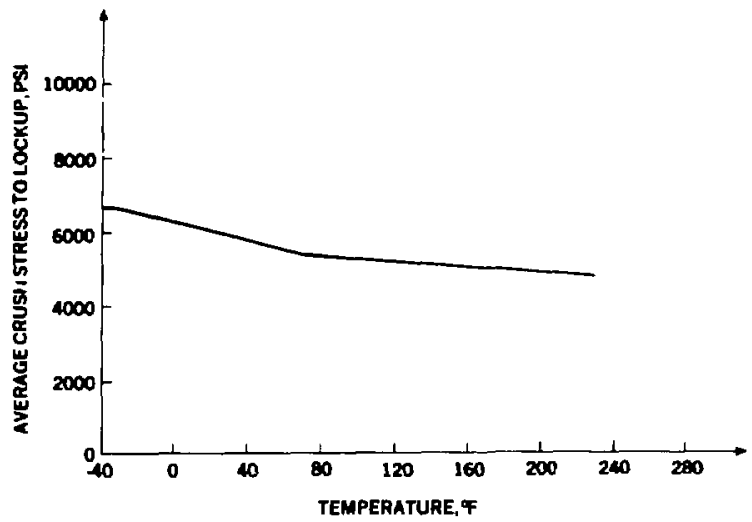

Figure 6. Average Crush Stress for Redwood as a l'unction of Temperature

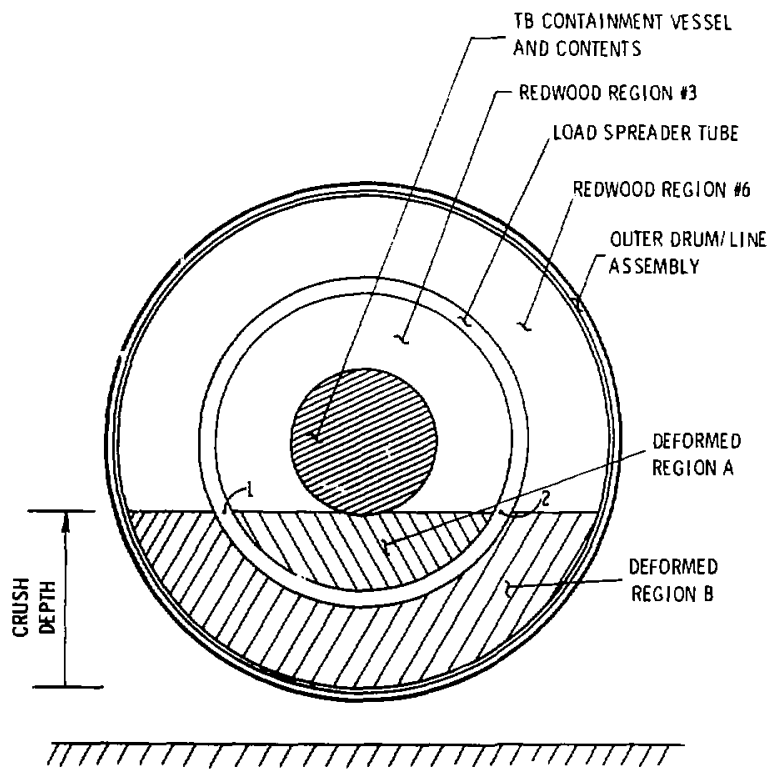

Figure 7. Impact Energy Balance 
"ai - diornation'constrution actior. also occurs in side and end impacts. Additionally,

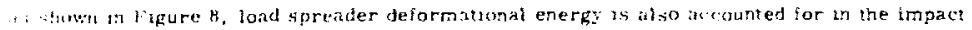

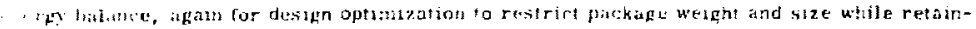

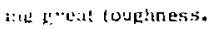

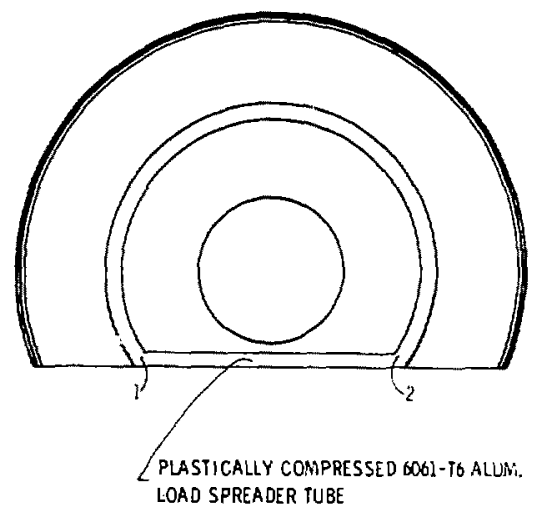

Figure 8. Impact Energy Balance

A photograph, Figure 9, of the resulting package cross-section shows the double-walled ouside drurs, the radial grain orientation of the outer and inner immuli of fedwood, the lond spreader tube, and the containment vessel. The non-removable elements of this assembly are permanenty bonded together with a polyester-nexibilized epaxy adhesive which has resilience over a wide temperature range. When impact lorces cause deformations, this bond acts in unison with the wooden elements and their adjacent metal elements.

\section{Containment Vessel (TB-1)}

The containment vessel, TB-1, Figure 10, consists of a body, a lid secured by bolts, $a$ copper gasket, and an O-ring. The vessel body and lid are labricated Iror: PH13-8, precipttation hardened stainless steel. The H1075 temper enhances ductility while preserving high strength from low to high temperatures. The TB body and lid are designed with approximately hemispherical end shapes and cylindrical side wall shapes to resist deformation from either external or internal loads or pressures. The lid is hermetically sealed to the body by the use of a ductile copper gasket in conjunction with knife edge sealing beads on both the body and lid, and a pattern of bolts, as shown in Figure 11. The sealing surfaces are arranged to afford handling 


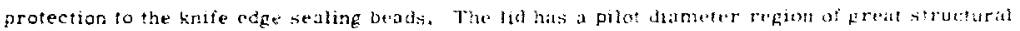

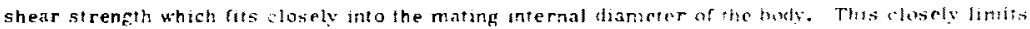

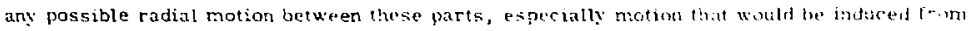

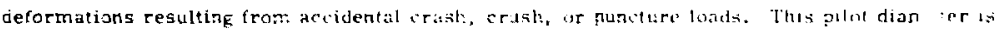
also equipped whth an ch-ring in a groove, its a secondary seal fo stimglemen he upper copper

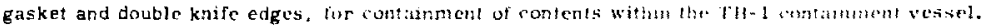

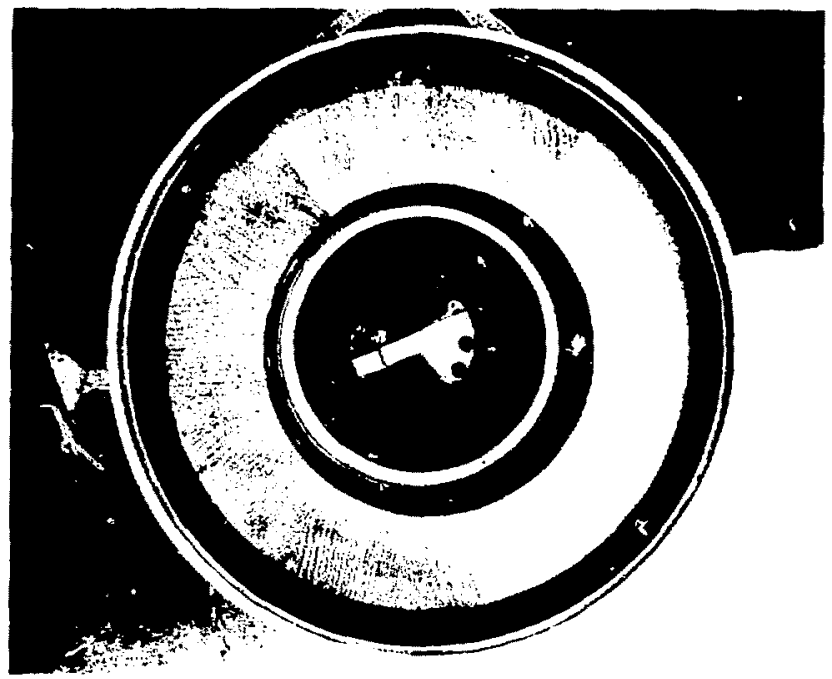

Figure 9. P'AT-1 P'ackage hiterior

The twelve TB-1 closure bolts, $1 / 2-\mathrm{in}$, in dzameter, shuwn in $/ 1 \mathrm{~g}$. 10, are forged from A-2B6 stainless steel, with over 30,000 10 ultimate tensile strenglh per bolt. This material resists corrosion in conjunction with the staintess steet TC-I body and lid, and provides high temperature strength to maintain the TB- 1 seal at elested temperatures. The bolis are silver plated to prevent galling of the stainless 5 teel bolt in the stainless situel vesset.

A shock mitigation spacer within the Th-1 containment vessel is faloricated from aluminum honeycomb (see Fig. 10) with axial cell orientation. This loneycomb spacer preventa the llat end of the PC-1 product can from entering inlo the hollow hemispherse idd in the case of severe impact loads in the axial directions. This spacer also serves as a thermal conductor for heat generated by certain $\mathrm{PuO}_{2}$ contents. 


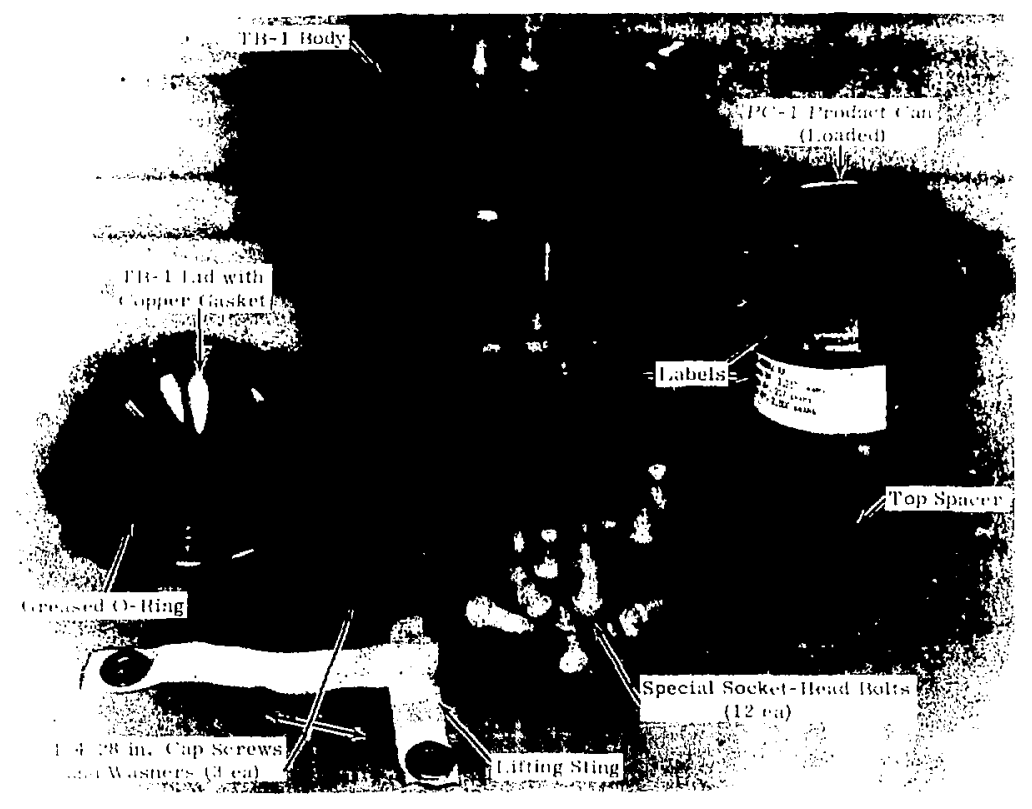

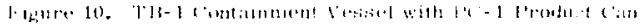

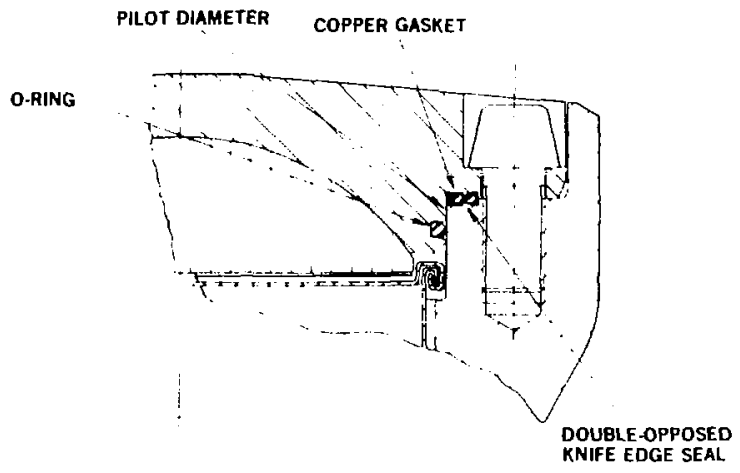

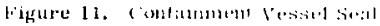


Finite element stress analysis (Fig. 12) was used to define the containment vessel design, leading to optimization of vessel mase, itself a threat to the surrounding shock mitigation material. The vessel was designed to directly accept impact and puncture threat, including armor piercing ballietic attack.

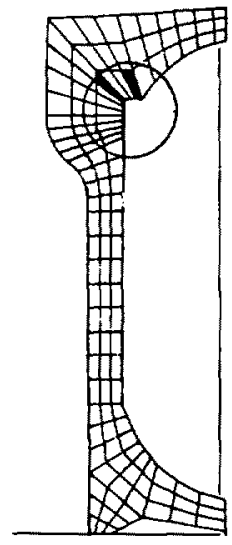

Figure 12. Containment Vessel Finile Element Stress Analysis

The TB-1 inner container is highly resistant to sea water corrogion and will withst and the hydrostatic pressures specified in the NRC Qualification Criteria.

\section{Product Can $(\mathrm{PC}-\mathrm{I}\}$}

The PC -1 product can, right side of Figuı 10 , is fabricated from stainiess steel. it is closeo by crinping in a canning machine and is also sealed with an epoxy material. The close fit of the TB-1 containment vessel limits product-can deflection or permagent change of shape under severe impact loads. The product can provides double containment under the normal and accident conditions of transport performance tests as specified by 19 CFR 71.42. This product can may be loaded to a maximum weight of $2 \mathrm{~kg} \mathrm{PuO}$ contents, not to exceed a maximum of $25 \mathrm{~W}$ thermal activity, of $\mathrm{PuO}_{2}$ of various lsotopic composition. 
Thermal analyses of the PAT-1 package included finite difference modeling for internal heat load capacity (Fig. 13), leading to the 25-W limitation on thermally active radioisotopic contents: the limiting consideration here was long-term protection of the redwood for pregervation of known performance factors, Finite difference thermal modeling was also used in the case of externally applied heat such as tine siandard hot day conitions (Fig. 14), and to predict package performance in the $1010^{\circ} \mathrm{C}\left\{1850^{\circ} \mathrm{F}\right\}$ large JP-4 jet fuel fire environment.
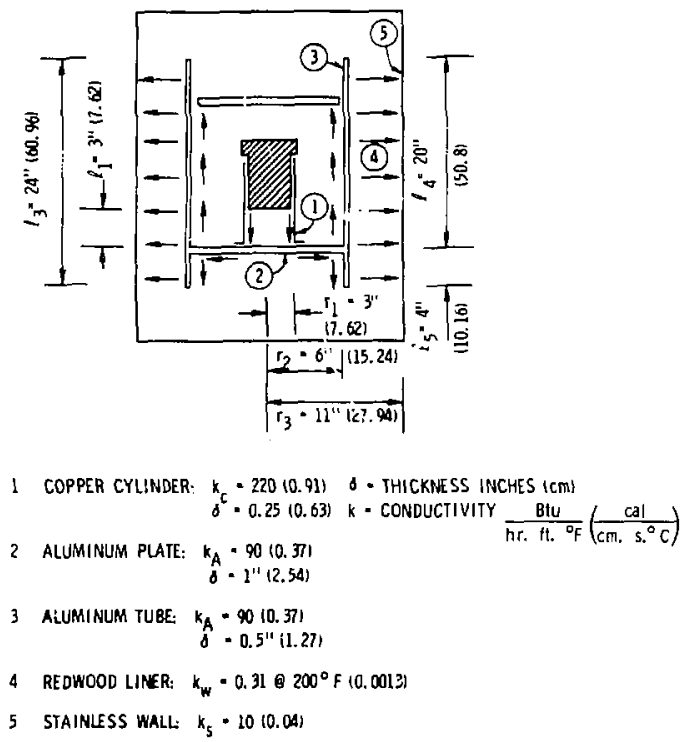

Figure 13. Finite Difference Internal Heat Model

Test Program

Test activities are best shown by a motion picture, "Plutonium Air Transportable Project," Sandia Laboratories, March 1978. Table III summarizes these tests and also indicates results. This table indicates that five PAT-1 packages were subjected to a similar sequential test series, with the initial impact test oriented so as to encompass the five different principle threat orientations of top, top corner, side, bottom corner, and bottor.l. The crush, puncture, slash, fire, 
and immersion tests that follow are essentially identical fur : :ll parkages, with the application point of each test being chosen to produce the most damaging cumulative effect on each parkage.

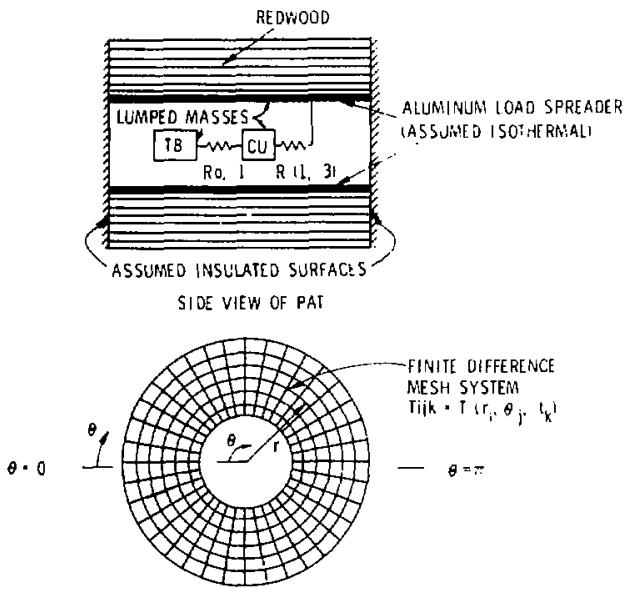

END VIE WH OF PAI

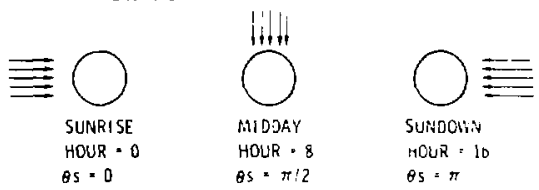

Figure 14. Finite Difference External lleat ilodel

Table IIl includes the individual hydrostatic test required by the Qwalification Criteria, and high and low temperature engineering development impact tests, applied as the first test in a sequential series.

Before the tests, each package was loaded with a finely divided surrogate $\left.1{ }^{\circ}\right)_{2}$ powder and helium gas. The results show that no uranium oxicle escaped as indicated by a fluorimetric test with a detection capability of $10^{-8} \mathrm{~g}$. Also, only very small helium leak rales were induced through the containment vessel seals, 
TABLE III

Summery of Quelification Testa, PAT-1 Package

\begin{tabular}{|c|c|c|c|c|c|c|c|c|}
\hline $\begin{array}{c}\text { Impact } \\
\text { Ortentation }\end{array}$ & $\begin{array}{l}\text { Impact } \\
\text { Vel, } 1 \text { to } \\
\text { Cinyt :lding } \\
\text { Target } \\
\text { (Ipg) } \\
\end{array}$ & $\begin{array}{r}\text { Crugh } \\
70,000 \\
\text { (lb) } \\
\end{array}$ & $\begin{array}{l}\text { Puncture } \\
\text { s000 } \\
(f t-2 b) \\
\end{array}$ & $\begin{array}{l}\text { Slash } \\
15.000 \\
(f t-1 b)\end{array}$ & $\begin{array}{l}\text { Fire } 2200^{\circ} \mathrm{F} \\
60 \text { Minuteg }\end{array}$ & Immeraion & $\begin{array}{l}\text { Cranium } \\
\text { Detection } \\
\geq 20^{-\beta} 8 \\
\end{array}$ & $\begin{array}{l}\text { Poat-Test } \\
\text { Alr } 1 \text { eakage } \\
\left(\mathrm{cm}^{3} / \mathrm{a}\right)\end{array}$ \\
\hline $\begin{array}{l}\text { Top } \\
a^{\circ}\end{array}$ & 442 & $\checkmark$ & $\sqrt{ }$ & $\checkmark$ & $\checkmark$ & $\sqrt{ }$ & nune & $<4,6 \times 10^{-6}$ \\
\hline $\begin{array}{l}\text { Tap } \\
\text { Corner } \\
30^{*}\end{array}$ & 451 & $\sqrt{ }$ & $\checkmark$ & $\sqrt{ }$ & $\sqrt{ }$ & $\checkmark$ & none & $\begin{array}{l}\times 4.5 \times 10^{-5} \\
\text { probably } \\
-1.7 \times 10^{-7}\end{array}$ \\
\hline $\begin{array}{l}\text { Side } \\
90^{\circ}\end{array}$ & 145 & $\sqrt{ }$ & $\sqrt{ }$ & $\sqrt{ }$ & $\checkmark$ & $\checkmark$ & none & $1.4 \times 10^{-6}$ \\
\hline $\begin{array}{l}\text { Bottarn } \\
\text { Corner } \\
150^{\circ}\end{array}$ & 443 & $\sqrt{ }$ & $\checkmark$ & $v$ & $\checkmark$ & $\sqrt{ }$ & none & $<5.5 \times 10^{-6}$ \\
\hline $\begin{array}{l}\text { Find } \\
180^{\circ}\end{array}$ & 466 & $\sqrt{ }$ & $\checkmark$ & $\checkmark$ & $\checkmark$ & $\sqrt{ }$ & none & $1.9 \times 10^{-6}$ \\
\hline & Individunl Tes & at: $600 \mathrm{p}$ & hydrosta & 8 hours & No detectabl & nater leaka & $<10^{-10}$ & \\
\hline
\end{tabular}

Experimental work with actual $\mathrm{PuO}_{2}$ was conducted under NRC sponsorsinip at another laboratory (Ref. 10), to correlate the observed helium leak rates with conservative bounding eatimates of worst-case possible plutonium loss (again, no surrogate powder escaped). Thege conservative jounding assessments of plutonium loss were compared to IAEA "A2" quantitieg, Table IV, by the $X R C$ staff. These assessments demonstrated successful performance of the PAT-1 package, satisfying the criteria for plutonium containment.

TABLE IV

Examples of Allowable Mass Release Rates -- LAEA "A2," Safety Series No. 6 and NUREG-0360

\begin{tabular}{llc} 
Isotope & $\begin{array}{c}\text { Normal Conditions of Transport } \\
(\mathrm{ug} / \mathrm{hr})\end{array}$ & $\begin{array}{c}\text { Accident Conditions of Transport* } \\
(\mu \mathrm{g} / \mathrm{wk})\end{array}$ \\
\cline { 2 - 3 } $\mathrm{Pu}^{238}$ & 0.000176 & 0.176 \\
$\mathrm{Pu}^{239}$ & 0.032 & 32.2 \\
$\mathrm{Pu}^{240}$ & 0.0087 & 8.7 \\
$\mathrm{Pu}^{241}$ & 0.0009 & 0.9 \\
$\mathrm{Pu}^{242}$ & 0.77 & 770 \\
Typical Mixture & 0.00255 & 2.55
\end{tabular}

These values are IAEA $B(11)$ quantities; NUREG-0360 and IAEA $B(M)$ allowed release is $10^{3}$ larger. 
Other

Other analyses conducted to detemine package conformance to the Qualification Criteria and to $10 \mathrm{CER} 71$ and $49 \mathrm{CFR} 173$ involve calculations for shielding and criticality. These results are summarized in Table $\mathrm{V}$.

TABLE V

Shielding and Criticality

\section{Shielding}

Normal Transport -- PAT-1 Package IJovides Sufficient Shielding ( 49 ( ${ }^{\prime} \mathrm{R}$ 173)

Required - < $10 \mathrm{mrem} / \mathrm{hr} 3 \mathrm{ft}$ from surface

Calculated - $4 \mathrm{mrem} / \mathrm{hr} 3 \mathrm{ft}$ from $\mathrm{AQ}-1$ - - horizontaliv

$1 \mathrm{mrem} / \mathrm{hr} 3 \mathrm{ft}$ from $A Q-1$ - verticall:

Required $\cdots<200 \mathrm{mrem} / \mathrm{hr}$ at surface

Calculated -- $30 \mathrm{mrem} / \mathrm{hr}$ at surface of $\mathrm{AQ}-\mathrm{I}^{\text {* }}$-- horizorialiy $15 \mathrm{mrem}$ ' hr at surface of $A Q-$ ! -- ver:ically

Postaccident -- Containment Vessel (TE-1) Provides

Sufficient Shielding (10 CFR $7 i$ ) -- This permits $A Q-1$ overpack to be discounted

Required - $<1000 \mathrm{mrem} / \mathrm{hr} 3 \mathrm{ft}$ from surface

Calculated - $8 \mathrm{mrem} / \mathrm{hr} \&$ [rom surface of TIB-1 -- horizonla]

- vertical

\section{Criticality}

Sormal Iransport -- Lndamaged Infinite Array $K_{\text {efi }} \sim 0.22$

Pastaccident -- Damaged Infinite Array (full consequence of Qualfication (riteria) $K_{\text {eff }} \sim 0.34$

Single Water-Flooded and Reflected TB- $1 k_{\text {eif }} \sim 0.62$

$\left(K_{\text {eff }}=\right.$ effective neutron multiplication factor $)$

Lsirg most radioactive recycled plutoniur. as conservalive source molel.

Table VI summarizes the results from testing the PAT-1 package to the requiren:ents of the present regulations, 10 CFR 71.

The integrity of the inner containment vessel, determined by both andlysis and test, is summarized in Table VII. 
TABLE VI

Results of $10 \mathrm{CFR} 71$ Qualification Tests, PAT-1 Package

Normal Conditions of Transport: Heat, cold, internal pressure, vibration, water spray, drop ( $4 \mathrm{ft}$ ), penetration, compregsion

- No Effect on Shielding

- No Effect on Criticality

-- No Release: Leaktight (leakrate $<10^{-10} \mathrm{~cm}^{3} / \mathrm{s}$ ) Containment Veasel No Release $\left(<10^{-8} \mathrm{~g}\right)$ of $\mathrm{UO}_{2}$ Surrogate from Product Can -- Duble Containment (product car and containment vessel both meet requirements)

Accident Conditions of Transport: Drop (30 ft), puncture, fire, immergion

- No Effect on Shielding

-- No Effect on Criticality

-- No Release: Leaktight (leakrate $<10^{-10} \mathrm{~cm}^{3} / \mathrm{s}$ ) Containment Vessel No Release $\left\langle\mathrm{10}^{-8}\right.$ g) of $\mathrm{UO}_{2}$ Surrogate from Product $\mathrm{Can}$

-- Double Containment (product can and containment vessel both meet requirements) 
TABLE VIL

Containment Vessel Integrity

Internal Pressure

-- Maximum Credíble Accident Environment -- $108{ }^{\circ} \mathrm{F}$, 1253 psi (Bounding Assessmient)

Testeo to: :000 $\mathrm{F}, 3330 \mathrm{psi}, 18 \mathrm{hrs}$

Many tests at $\sim 1080^{\circ} \mathrm{F}, \sim 1253$,si

Aralysis 18,300 pst gtress

93,000 psi strength

At $1080^{\circ} \mathrm{F}$ and $1253 \mathrm{pa1}$, Margin of Safety $\simeq 4$

-- Maximum Normal Operating Pressure -- $215^{\circ} \mathrm{F}, 34.3$ pai

. vialysis 405 pgi stress

$140,000 \mathrm{psl}$ strength

At $215^{\circ} \mathrm{F}$ and $34.3 \mathrm{psi}, \mathrm{Margin}$ of Safety $\simeq 306$

\section{External Presgure}

-- Hydrostatic Requirement -- 600 pgi

Tested to: 5,000 psi: No leak

Analysis 5,000 psi load produces $-43,000$ psi stress

150,000 psi strength gives Margin of Salety $\simeq 2$. 5

Margin of Safety $\simeq 20$ at $600 \mathrm{ps}$

Conclusion

The PAT-1 package, developed in the PAAC progran, survives the severe accident-modeling test threats of the Qualification Criteria, meets the acceptance criteria for containment, shielding, and criticality, and provides a safe means for air transport of plutonium. 


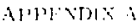

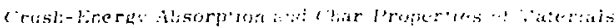

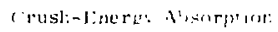

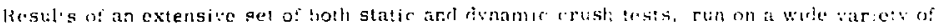

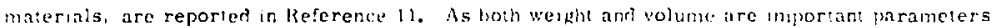

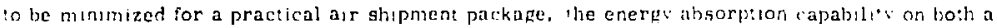
weicht and volume basis is considered. The energy absorhed las measured bu the area under :he corce-teflection curve of the mater:al) per unlt mass and per tri: volume of the ma:erial :s ndica:ed : $n$ Findres $A-1$ and $A-2$ for a represen:alıve se: of ma:erials aker from :he 45 ira:er:als tested. ${ }^{11}$ It is clear that woods such as redwood, balsa, and poplar (loat applied parallel to the grajnl are quite promising when compared to such materials as metal and plastic honevcomh or roamed riaterials.

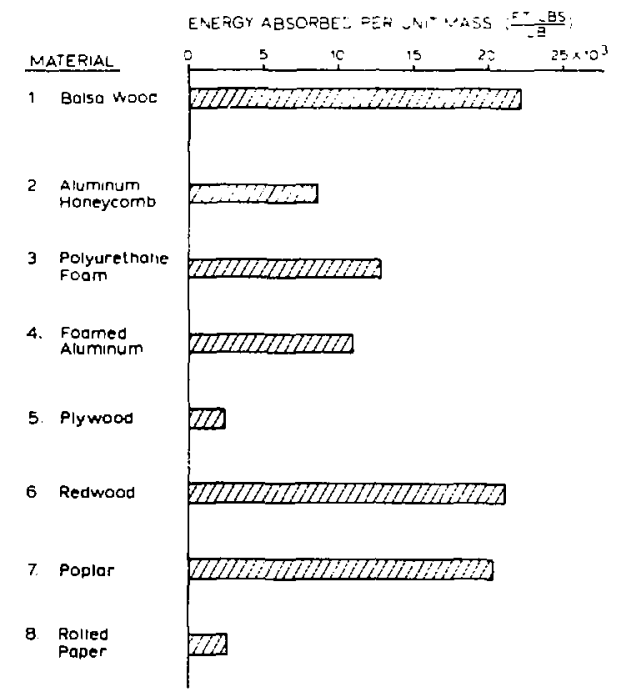

Figure A-1. Ënergy Absorherl per l'nil hiass of llaterı11 


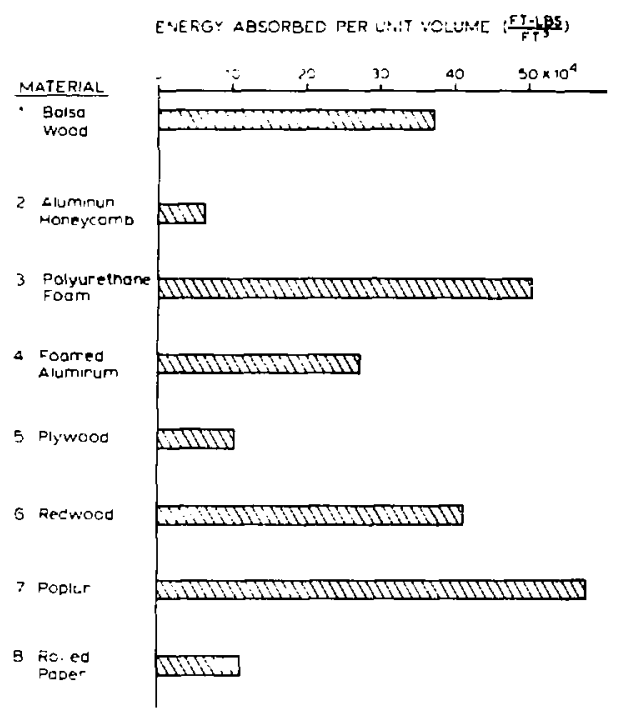

Figure h-2. Energy nbsorbed per Lnit Volume of Material

Char Properties or Materials

Data on the char depth as a function of $t$ ime were obtained on a number of different materials, including $23 \mathrm{lb} / \mathrm{rt}^{3}\left(368 \mathrm{~kg} / \mathrm{m}^{3}\right)$ redwaod.

The experimental setup consisted of a hallow, cylindrical sample subjected on ita outer surface to a $1850^{\circ} \mathrm{F}\left(1010^{\circ} \mathrm{C}\right)$ temperature, which simulates a $1850^{\circ} \mathrm{F}\left(1010^{\circ} \mathrm{C}\right)$ blackbody fuel fire. Thermocouples were placer at various radial locations inside and at inner and outer surfaces of the cylindrical sample; temperature, as a function of time, was recorded. The average char velocity was determined as the distance into the material at which a temperature of $550^{\circ} \mathrm{F}\left(288^{\circ} \mathrm{C}\right)$ was recorted (the thermocouple location) divided by the time at which this temperature was observed. As discussed in Reference $8,550^{\circ} \mathrm{F}\left(288^{\circ} \mathrm{C}\right)$ is representative of cellulose charring temperature.

The char velocity data were graphically integrated (Figure A-3). The clear superiority of redwood oves balsa woot in fire resistance capability is readily apparent. Based upon the combination of energy absorption and charring capabilities, redwood was chosen for use in the PAT-1 package. 


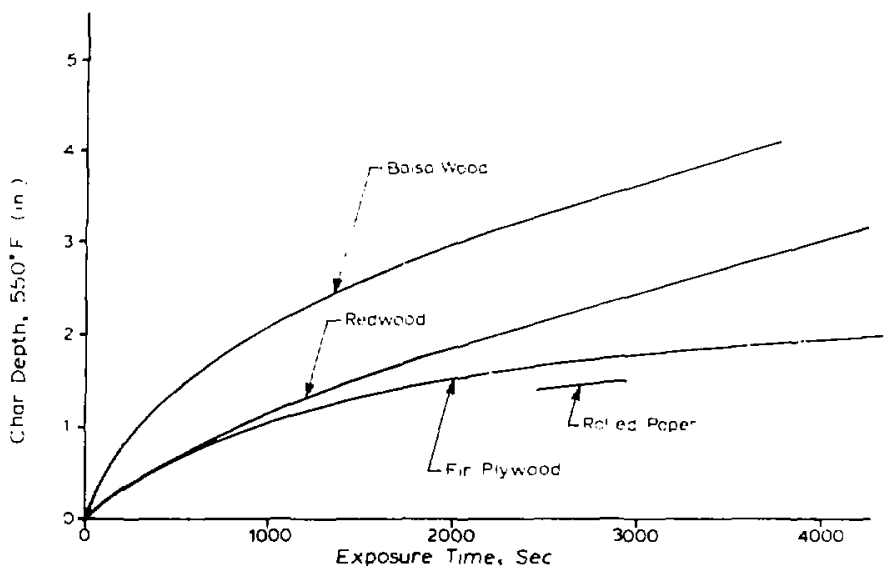

Figure A-3. Comparison of Char Depths (Distance of Fixposure Surface to $550^{\circ} \mathrm{l}$ ) Point) versus $\mathrm{T}$ ime for an $1850^{\circ} \mathrm{F}$ Blackbody Radiation Source

Additional Redwood Crush Data

Additional new data on the mechanical properties of redwood were found to he necessarvin order to develop a package hesign to meet the severe demands of the qualification criterit.

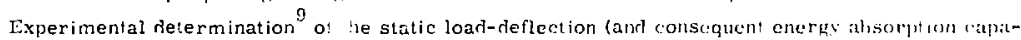
bility) behavior of redwood corr. : ressed parallel to the grain was obtained by ririving a crintrical plunger with a cross sectional area of one square inch $\left(645 \mathrm{~mm}^{2}\right.$ ) into restraired three-irch (76-mm) redwood cubes. The variation of redwood crush load with temperature for all tests perforned is indicated in Figure A-4, ${ }^{9}$ Although considerable scatter is present, a trend of decreasing strength with increased temperature is clearly evident. It was also found !hat crush loar is reasunably: cons:ant with deflection until "bottoming out" of the material occurs. Fiqure A-j presents the average crushing stress across the temperature range of interest.

The specific energy abscrbed by the redwood specimens over the temperature range of interest is presented in Figure A-6. ${ }^{9}$ Figure A-6 also shows static and dynamic data prinis taken from other work performed at Sintia Laboratories. ${ }^{11}$ Rensonable agreemicnt between static and dynamic test results lends justif sation to the use of static data for dynamic crushing capahility design estimates. 


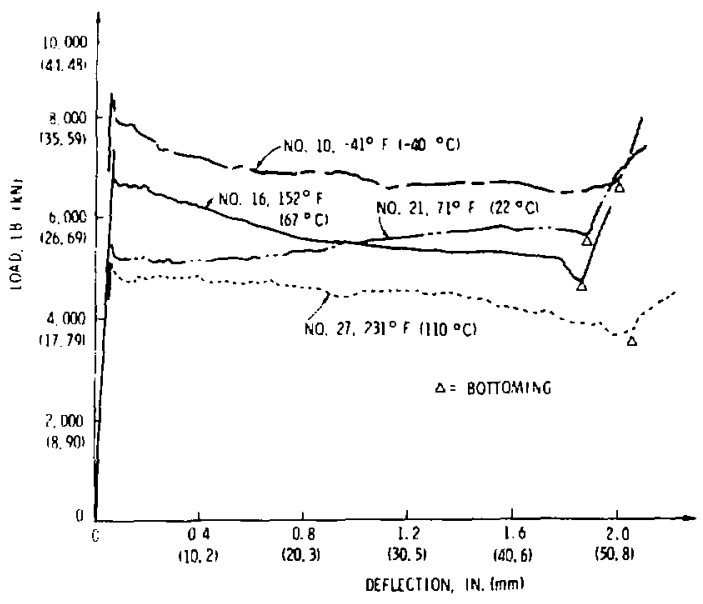

Figure A-4. Typical Load-Deflection Curves for Redwood

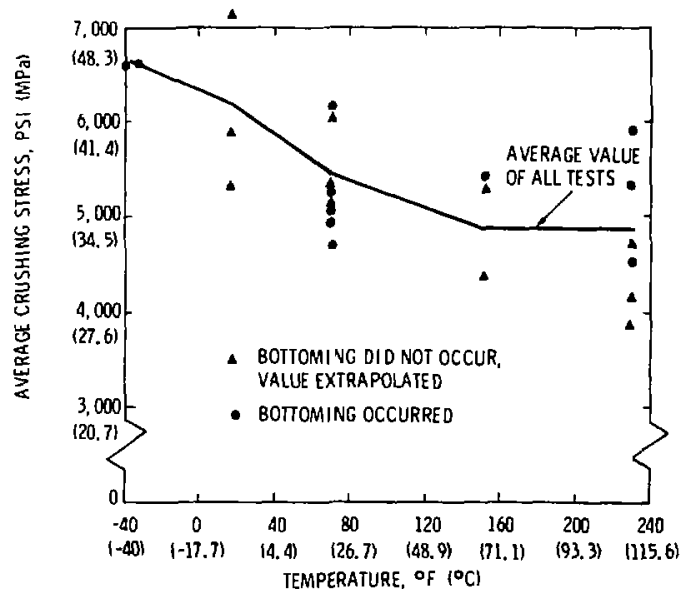

Figure A-5. Average Crushing Stress vg. Temperature for Redwood 


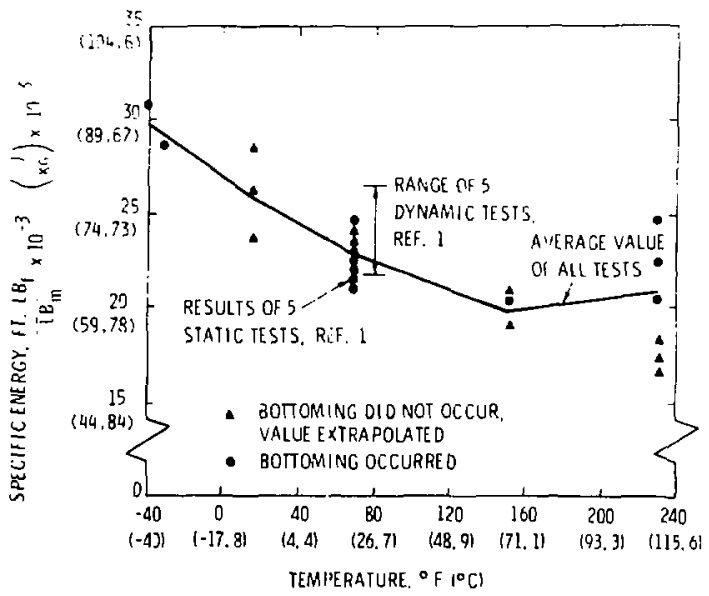

Figure A-6. Specific Energy vo. Temperature for Redwood 


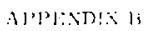

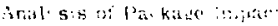

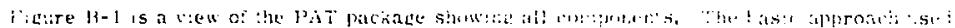

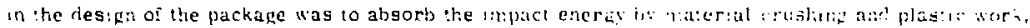
the alm being to isolate the inner conta.ier from excessuc shock, while retaunin crisherl-up material as a thermal barrier for the subfequent intense fire.

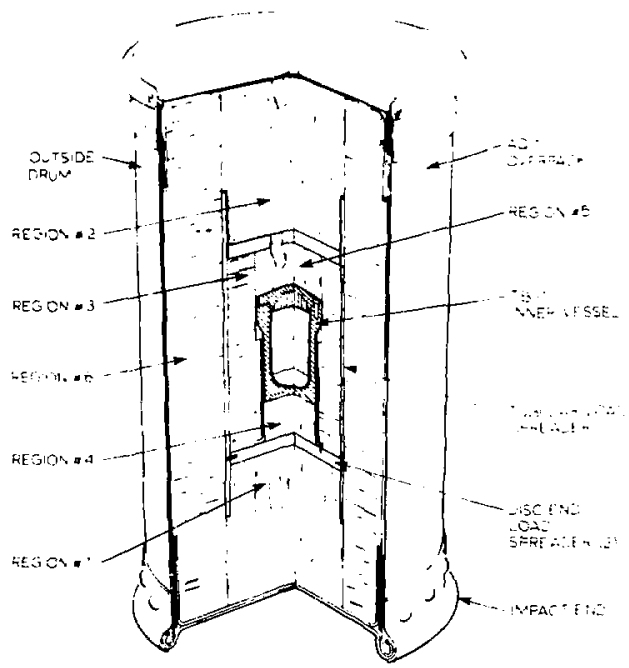

Figure B-1, Regions Csed in Energy Balance ('alculations

The inner container can be envisioned as a rigid, massive, but fairly small object whose motion must be stopped primarily by redwood crushing. A load spreacler assembly is incorporated around the inner container to distribute the inertial loading over a larfer area of the redwood than would be caused by the projecteri area of the inner container alone. 
The ablltu of lie PAT-t package to strvive a 422 fpg $(12$ ? $\mathrm{r}$ 's) perpendicular impact on an unvelfing tartet was analyzer for both sirle-on and enf-on configurations by means of an elementary enerev bance appraach.

The ent on impar" process is assumet to he one-dimengional. Such an agsumption lo deemed rspevialls appropriate for redwoor compressed in a direction parallel to the grain, based upon the observed response of redwort so compressed turing the material property tests. 11

The rolun of material isolating the inner container consists of regione 1, 2, 3, 4, and 5 (1-jeure 13-1) as well as t!e iwo lisc end loat spreaders, It is assumed that at the time of impact ihis rolimn 'ias a rigin holv kinetic energy corresponding to the $422 \mathrm{fps}(129 \mathrm{~m} / \mathrm{g})$ Impect velocity הn ll:e ntal mass of all rialerials in the rolimn.

for a suressful design, the kinelic energy attributert to the tatal rigin body motion must be ahsorber hi permanent fleformational energy of the redwood material. It is assumed that the kimetir energy of the entire col.mn is [all" absorbed by redwood regions 1 and 4 only. Si:ch an ass'mpior: neuler!s the aissorption capability of regions 2, 3, ; and deformation of the two load spreaters, and is therefore conservative.

When the initial regir? bory kinetic energy before impact is compared with the total energy which can he absorbet hy redwoot in regious 1 and 4 (crushing to the point of lockupl, a positive marcin of safety for end-on container impact is present which indicates the adequacy of the design.

i similar enercy balance approach was taken for side-on impact, that is. initial rigid body kinelic energu was equated with energy absorbed by crushing of redwood material.

Eriv in the Hesign phase of the package, many energy balance calculations were performed in an atfempt to arrive at a practical optimization of mass, stringth, and numbers fe. g., one or more interstitial shells) of load spreaders, and also to judge the affordable mass (and hence strength) of the inside vessel. Computer-generated design iterations were judged from the viewpoint of available economic materials and fabrication costs of grain-oriented redwood annular shells and pluas embetier in metal tubes and plates.

A more complete trealment of the enercy-halance impact analysis is presented in Reference 7 . 
1. Nuclear Regulatory Commission, Qualification Criterla to Certify a l'uckage for Air Trunsport of Plutonium, (NUREG-0360), NRC draft, January 1978.

2. Leakage Tests on Packageg for Shipment of Radioactive Miaterialy, ANSI Siardard N14. 15, 1974, American National Standards Institute, 1430 Broadway, New Yirti, Vy.

3. Regulations for the Safe Transport of Radioactive Baterials, Intermitional Atomm labers?

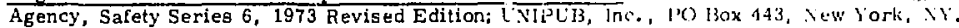

4. Nuclear Regulatory Commission Appropriation Authorization, Public l. aw 94-79, 174-1 Congress, líashington, DC, August 9, 1975.

5. Packaging of Radioactive Material for Transport and Transportation of Iadioactive Material Lnder Certain Conditions, Title 10, Code of Federal Regulations, Purt 71, revised hugust I 9 , 1575 .

6. Transportation, Title 49, Code of Federal Regulations, lart 173, fumiry 1, 1973.

7. J. A, Andersen, et al., PARC (Plutonium Accident Resistant Container) Research, Design, anc? Development, SAND76-0587, Sandia Laboratories, Albuquerque, Nh, July 1978.

8. R. E. Berry, et al. Accident-Resistant Container: Materials and Structures Evaluation, SAx 274-0010, Sand1a Laboratories, Albuquerque, NM, August 1975.

9. W. A. Von Riesemann and T. R. Guess, The Effects of Temperature on the Energy-Absorbing Characteristics of Redwood, SAVD77-1589, Sandia Laboratories, Albuquerque, Nit, 1978.

io. L. C. Schwendiman, et al., Quarterly Progress Report, October 1. 197 a-1)ecmber 31, 1077.

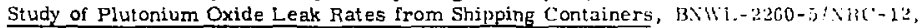
Battelle Pacific Northwest Laboratories, Richland, $15 \Lambda$, Jantury 1978.

11. T. K. Hill and W, W. Joseph, Energy-Absorbing Characteristıcs of Naterials, SLA74-0159, Sandia Laboratorie日, Albuquerque, NM, May 1074. 


\author{
DISTIIBTTION: \\ I.S. Nuclear kegulatory Commission (50) \\ Washington, DC 20555 \\ A.tn: W. T,ahs (25) \\ Office of Nuclear Regulatory Fesearch \\ (.) E, Macdonald (25) \\ Office of Nuclear Mall. Safety and \\ Safepuards Transportation $\mathrm{Br}$.
1223 Il. E. Guttmann
$1+14$ A. 1. l.uhrs
I 7 fion I. A. Andergen (2.5)
i7f0A W. F. Ilariman
24.73 P. R. Oweng
3151 A. C. Wallace
$+2: 31$ S. A. Dupree
th:30 H. M, leflerson $(10)$
+43 W. A. Von liesemann
4til C. M. Stone
$4+3.3$ R. H. Pope $(50)$
4433 H. .1. loseph
443.3 S. 11. Sutherland
15.33 L. S. Nelson
55 i.3 H. 11. Nilson
5631 1. A. Stark
56.3. 1. h. tole
5 HI3 N. I. Delollis
5832 C. II. Naak
7266 F. A. Aas
.1141 T. T. Werner (5)
3151 W. L. Carner (3)
For DOE;TIC (Linlimited Release) \\ DOE!TIC (25) \\ (I. P. Camplell, 3172-3)
}

